\title{
$\longrightarrow$ \\ Los Comités de Agua Potable y Saneamiento \\ y la gestión social de un bien común en Nicaragua. Los casos de los CAPS de El Edén y Chompipe
} AGUA YTERRITORIO

\author{
The water and sanitation committees and the social management \\ of a commong good in Nicaragua. \\ The cases of the El Edén and Chompipe
}

\author{
Rosibel Kreimann
} Instituto de Estudios Latinoamericanos. Universidad Libre de Berlín. Berlín, Alemania. rkreimann@zedat.fu-berlin.de

Resumen - La investigación presentada en este artículo se llevó a cabo en el marco de la Maestría en Estudios Urbanos de El Colegio de México (2007-2009). Se presenta un análisis comparado de la gestión social del agua que realizan los Comités de Agua Potable en Nicaragua. Estas son organizaciones que satisfacen a un $23 \%$ de la población, trabajando para llevar agua a las comunidades en sectores rurales y de la periferia urbana.

La gestión social de los Comités se estudia desde la perspectiva de gestión común basada en el planteamiento de Elinor Ostrom, donde es la acción colectiva de los pobladores - a través de la construcción de normas comunes para desarrollar estrategias en relación a otros actores- lo que les permite llevar a cabo su labor.

Para contestar a las interrogantes centrales del estudio: :Los Comités de Agua Potable y Saneamiento en Nicaragua gestionan el agua como un bien común? ¿Esta gestión se desarrolla de manera diferenciada en contextos rural y de periferia urbana? se retoman dos casos significativos en el país: el Comité de Agua El Edén en un contexto periurbano en la capital, dentro del área de amortiguamiento de la Reserva Natural Chocoyero-El Brujo; y el Comité de Agua Potable El Chompipe en un contexto rural, organizado en una Red de Agua a nivel municipal.

De esta manera, el interés es analizar si la gestión se da de una manera colectiva, y cómo esto se ve influido por el contexto geográfico en que se encuentran los Comités. Para ello se llevaron a cabo dos etapas de trabajo de campo en Nicaragua, en el que se realizaron entrevistas con actores gubernamentales y no gubernamentales, entre estos últimos los Comités de Agua Potable, tanto a nivel nacional y de las localidades seleccionadas. En este artículo, a diferencia de publicaciones anteriores, además del interés por mostrar la importancia de los hallazgos en los dos estudios de caso dentro del contexto socio-institucional del país, es de interés enfatizar en el proceso metodológico seguido en la investigación.

Abstract - The research presented in this article was carried out as part of my Masters in Urban Studies at El Colegio de Mexico, Mexico City (2007-2009). I present here a comparative analysis of cases of social management of water in Nicaragua's Water and Sanitation Committees (CAPS in Spanish). CAPS serve around $23 \%$ of the population in rural communities and peripheral urban areas. I studied the social management carried out by the committees drawing on Elinor Ostrom's perspective about the management of the commons. Ostrom emphasised that the collective action of the population is the key for the success in managing the commons, and this is only possible through commonly agreed norms to develop strategies in relation to other actors. The main questions posed by the study were: Do CAPS in Nicaragua manage water as a common good? Are there any differences between rural and peripheral urban areas in relation to water management by the CAPS? I studied two relevant cases: a) the CAPS El Edén, located in a peripheral urban area of Managua, within the Chocoyero-El Brujo Natural Reserve, and b) the CAPS El Chompipe, located in a rural context and organized as a municipal water network. The main interest of the article is on identifying to what extent water management is carried out as a collective activity and how the geographical locations of the CAPS may affect their operation. I carried out my fieldwork in two stages that included interviews with national and local governmental and non-governmental actors, including members of the CAPS in the two communities. This article discusses the importance of the research findings within the framework of Nicaragua's socio-institutional context and describes the methodological process followed in the research.

Palabras clave: comités de agua, gestión social, bien común, Nicaragua

Keywords: water committees, social management, common good, Nicaragua 